\title{
A VERDADEIRA PARTICIPAÇÃO NOS LUCROS
}

A. F. CESARINO JÚNIOR

\begin{abstract}
“Contra a participação direta há, pelo menos, três objeçóes fundamentais: a) dificuldade quase insuperável de estabelecer o critério de sua fixação; b) exclusão do benefício dos empregados de emprêsas que, eventualmente, não produzam lucros; c) exigüidade do benefício e conseqüente desinterêsse do trabalhador pela sua percepção." - ALBERTo PASQUALINI
\end{abstract}

A participação nos lucros, assunto discutido há mais de dois séculos, volta presentemente a preocupar os que se interessam pela solução da Questão Social. Contribuíram grandemente para isso as palavras do Papa JoÃo XXIII na encíclica Mater et Magistra, n. ${ }^{\circ} 73$ e 74: "A êsse propósito convém recordar o princípio exposto pelo nosso predecessor PIo XI na encíclica Quadragésimo Anno: "É completamente falso atribuir só ao capital ou só ao trabalho aquilo que se obtém com a ação conjunta dum e doutro; e é também de todo injusto que um dêles, negando a eficácia da contribuição do outro, se arrogue sòmente a si tudo o que se realiza'." ${ }^{1}$ "Essa exigência de justiça

Antonto Ferreira Cesarino Júnior - Professor das Faculdades de Direito e Economia da Universidade de São Paulo e de Medicina da Pontifícia Universidade Católica de São Paulo, Presidente Honorário da Sociedade Internacional de Direito do Trabalho e de Segurança Social e Professor Honorário da Universidade Central da Venezuela.

1) AAS XXIII, 1931, pág. 195. 
pode satisfazer-se de diversas maneiras que a experiência sugere. Uma delas, e das mais desejáveis, consiste em fazer que os trabalhadores possam chegar a participar na propriedade das emprêsas, da forma e no grau mais convenientes. Pois nos nossos dias, mais ainda que nos tempos do nosso predecessor, é necessário procurar com todo o empenho que, para o futuro, os capitais ganhos não se acumulem nas mãos dos ricos senão na justa medida, e se distribuam com certa abundância entre os operários." A referência acima bastaria para demonstrar a importância do assunto. Entretanto, o próprio fato de dêle se haver cogitado durante mais de dois séculos evidencia igualmente a sua relevância.

\section{CONCEITUAÇÃo}

Definimos participação nos lucros como sendo a atribuição facultativa ou obrigatória pelo empregador ao empregado, além do justo salário legal ou convencionalmente a êle devido, de uma parte dos resultados líquidos exclusivamente positivos da atividade econômica da emprêsa. Para tornar bem claro o conceito de participação nos lucros é importante estabelecer a distinção existente entre ela e outros institutos com os quais pode ser confundida, como aliás tem acontecido. São êles, notadamente, o salário-incentivo, o contrato de sociedade e a cogestão. Vejamo-los um a um.

\section{A. Participação nos Lucros e Salário-Incentivo}

Sendo a participação nos lucros o ter o empregado parte nos "resultados líquidos" da emprêsa, evidentemente se distingue das diversas formas de salário-incentivo (salário proporcional, salário-renđimento, prêmios de produção, participação na produção, Sistema Taylor, Sistema Rowan, Sistema Schueller etc.) em que o empregado não participa dêsses ganhos, mas tão-sòmente do acréscimo de

2) Ibidem, pág. 198. 
produção devido, em grande parte, aos seus esforços. ${ }^{3}$ Ora, os lucros podem ser determinados por outros motivos, tais como a situação do mercado, o câmbio favorável etc.. Adiante demonstraremos melhor essa distinção.

\section{B. Participação nos Lucros e Contrato de Sociedade}

A participação nos lucros, por si só, não faz originàriamente do empregado um sócio da emprêsa. O que pode causar essa situação é a inversão (fato posterior) de seu importe em cotas-partes ou ações do capital da emprêsa quando ela assume a forma acionária. $O$ mesmo se deve dizer quanto à parceria, que é um verdadeiro contrato de sociedade, nada tendo que ver com a participação nos lucros. O elemento importante de distinção é que no contrato de sociedade e na parceria há participação tanto nos lucros como nas perdas. Ora, isso não acontece na participação nos lucros que, por definição, o é sòmente nos lucros, isto é, nos resultados positivos. ${ }^{4}$

\section{Participação nos Lucros e Cogestão}

Igualmente, da simples participação nos lucros não decorre a cogestão, isto é, a administração da emprêsa, em conjunto, pelo empregador e pelos empregados. Tanto essas coisas são distintas que podem existir separadamente, como acontece na Alemanha. Esta possui a cogestão ( $M i t-$ bestimmungsrecht), mas não, obrigatòriamente, a participação nos lucros. ${ }^{5}$

3) ARThur BIRNIE, História Econômica da Europa, Rio de Janeiro: Zahar, 1964, págs. 225/234.

4) ARnaldo Sussekind, Comentários à Consolidação das Leis do Trabalho, Rio de Janeiro: Freitas Bastos, 1963, vol. III, págs. 359/364.

5) HANS CARL NIPPERDDEY, Lehrbuch des Arbeitsrechts (Kollektives Atbeitsrecht), Berlim: Franz Vahlen, 1957, vol. II, pág. 673; Rolf DIETZ, Die Beteiligung der Arbeitnehmer a der Leitung am Gewinn des Unternernehmens, Berlim: Walter De Gruyter, 1958. 
FUNDAMENTOS

A participação nos lucros se fundamenta em motivos de ordem filosófico-social, psicológica, econômica e jurídica.

\section{A. Fundamentos Filosófico-Sociais}

Os principais fundamentos filosófico-sociais da participação nos lucros se encontram na Teoria Institucional e na Doutrina Social Católica.

- Teoria Institucional - Segundo Georges RENARD, é caraterístico do reconhecimento da teoria do instituição "a mistura de um elemento de sociedade ao contrato de trabalho". ${ }^{6}$ Ora, já vimos que a participação nos lucros tanto aproxima o contrato de trabalho do de sociedade, que tem dado lugar a confusões entre os dois institutos.

- Doutrina Social Católica - A Doutrina Social Católica é explícita acêrca da participação nos lucros. Assim PIo XI na Encíclica Quadragesimo Anno: "Nas hodiernas condições sociais julgamos seja mais prudente que, na medida do possível, o ajuste do trabalho venha a ser temperado um pouco com o contrato de sociedade, conforme já se principiou a fazer de diversas maneiras, com não poucas vantagens para operários e patrões. Destarte, os operários se tornam co-interessados ou na propriedade ou na administração, e compartes, em certa medida, nos lucros auferidos". E JoÃo XXIII o esclareceu na Mater et Magistra, conforme já citamos. Por sua vez, o Código Social da União Internacional de Estudos Sociais, de Malinas, estatui no art. 134: 'L'institution du salariat n'est point en elle-même injuste et ce serait une erreur que de vouloir y substituer systèmatiquement, entre capitalistes et travailleurs, un règime de société qui partagerait gains et parts. Il est cependant plus approprié aux conditions actuelles de la vie sociale de tempérer, dans la mesure du possible, le contrat de salariat par des éléments empruntés au contrat de la société".

6) Cf. Da Philosophie de I'Institution, Paris, 1939, pág. 195. 
A respeito cumpre lembrar a lição de VAN GESTEL: "Essa integração do trabalho na comunidade da emprêsa pode realizar-se sob tríplice aspecto: pela participação nos lucros, pela cogestão e pela copropriedade. Mas, no pensamento de Pro XI, as reformas de estruturas devem estender-se também à profissão e a tôda a vida social e econômica. De modo esquemático, podem ser representadas da seguinte maneira: 1. Na emprêsa: participação nos lucros; cogestão; copropriedade." 7

\section{B. Fundamentos Psicológicos}

Se a motivação do empresário é o lucro, porque a do empregado há de ser sòmente o salário? Além dêsse aspecto econômico, êle tem também o interêsse moral de se sentir integrado na emprêsa. E' o caso de lembrar, com GILMER: "La gran cantidad de investigaciones experimentales en esta rama, llevadas a cabo en el Survey Research Center de la Universidad de Michigan, ha permitido a KATZ ofrecer cuatro dimensiones de la moral: 1 . La moral implica la satisfacción intrínseca en el trabajo. 2. La moral implica orgullo por el grupo de trabajo. 3. La moral implica satisfacción por salarios y oportunidades de ascenso. 4. La moral implica identificación con la empresa." "REMUNERACIÓN - Cuando este factor se alinea con los otros nueve factores laborales los empleados le ortogan el cuarto lugar. Es interesante hacer constar que los empleados colocan generalmente este factor cerca del pri-

7) VAn Gestel, A Igreja e a Questão Social, Rio de Janeiro: Agir, 1956, pág. 246.

8) B. Von Haller Gilmer, Psicologia Industrial, Barcelona: Grijalbo, 1963, págs. 259 e 265. Cf., a respeito, J. A. C. BRown, La Psicologia Social en la Industria, Méxicc: Fondo de Cultura, 1958, pág. 230, verbis: "La creencia de que el dinero es el único motivo, o por lo menos el más importante de los motivos para trabajar, es tan estúpida. que cualquiera que la sostenga seriamente queda automaticamente incapacitado para comprender la industria o al trabajador industrial. El trabajo es, fundamentalmente, una actividad social que cumple dos funciones principales: producir los bienes que la sociedad necesita e integrar al individuo en los sistemas de relaciones que constituyen la sociedad". 
mer puesto cuando se les pergunta lo que quieren. Sin embargo, hay algunas indicaciones de que la remuneración y las oportunidades de progresar van unidas a través del elemento dinero. Algunos empleados conscientes han clasificado a los salarios como de menor importancia que la oportunidad para ascender a la seguridad. Los estudios demuestran que el factor remuneración contribuye más a la insatisfacción que a la satisfacción del trabajador. Muy taras veces expresa alguien su satisfacción por la cantidad de dinero que percibe. La remuneración es más importante para los hombres que para las mujeres y generalmente más para los obreros que para los oficinistas. HERzBERG y sus colaboradores afirman que hay una tendencia a que la importancia del salario descienda con la edad de los empleados, por lo menos hasta los cuarenta años. Después de los cuarenta los empleados dan mayor importancia al factor salario, considerando que los factores de trabajo, empresa, seguridad y otros parecen haber llegado a una buena estabilización.” M. CoUMETOU afirma que para "realizar êsse sentimento íntimo, na posição em que a emprêsa o colocou, o trabalhador deve pôr sua conduta pessoal em harmonia com a função que lhe é confiada: essa integração funcional, possivel em caso de convergência dos interêsses da emprêsa e do trabalhador, faz dêle não mais uma rodagem mecânica, mas membro duma organização".

\section{Fundamentos Econômicos}

A análise do processo econômico demonstra que na produção intervêm quatro fatôres (sem falar no Estado, como fator de segurança): natureza, capital, trabalho e, com grande relêvo, a organização. Esta, personalizada no empresário, é que congrega aquêles três fatôres. $\mathrm{Na}$ verdade, é o empresário quem organiza a emprêsa, proporcionando-lhe com o capital - seu ou obtido por êle de ou-

9) Citação de E. W. BARKE no capítulo L'activité professionelle et ses facteurs, do Traité de Psychologie Appliqué, sob a direção de H. PIERoN, Paris: Presses Universitaires, 1960, vol. II, pág. 1152. 
trem - as instalações, os maquinismos, móveis, utensílios e matéria-prima necessários (fator natureza), e recrutando o trabalho de execução necessário. Daí o fato de porque êle representa, além da organização, também o capital e a natureza - ser, em conjunto, denominado apenas Capital, em oposição àquele último, o trabalho de execução, chamado apenas Trabalho. A necessidade da colaboração e da atividade de ambos (representada esta última pelo trabalho de direção, do empresário, e pelo trabalho de execução, do empregado) é indiscutível.

Cada um dos cinco fatôres citados tem, tradicionalmente, uma remuneração específica: o Estado, o impôsto; o empresário, o lucro; o capital, o juro; a natureza, a renda da terra; o trabalho, o salário. Entretanto, essa distribuição tradicional do produto da atividade econômica da emprêsa não é exata. Com efeito, o salário remunera mais ou menos bem (antes menos do que mais) o trabalho de execução do empregado. Acontece, porém, que o empregador, o empresário, também tem uma remuneração específica pelo seu trabalho de direção, a retirada pro labore, que é levada à conta de despesas gerais. E, para remunerar sua colaboração, fica com todo o lucro. Não é assim remunerada a colaboração do empregado, ao qual, portanto, assiste o direito de participar, com o empresário, dos lucros líquidos da emprêsa.

\section{Fundamento Jurídico}

Do fundamento econômico resulta o fundamento jurídico da participação nos lucros. Ex facto oritur jus. A participação nos lucros é, assim, não o efeito de mera liberalidade do empresário, nem de simples acôrdo bilateral ou multilateral, mas, na feliz expressão de LINDoño, "um direito natural do trabalhador". ${ }^{10}$ Ainda sob o aspecto jurídico, a participação nos lucros pode ser examinada:

10) Cf. cb. cit. na nota 13. No mesmo sentido Gustavo Lagos Matus, El Problema Historico del Trabajo, 1950, pág. 202. 
- Quanto à natureza - a participação pode ser voluntária, conforme resulte de um contrato ou de uma convenção coletiva de trabalho, ou obrigatória, se oriunda de lei.

- Quanto à forma - pode ser direta, se atribuída imediatamente aos empregados; indireta, se sòmente o beneficiar remotamente, por ser invertida, digamos, em obras de assistência social realizadas pela emprêsa ou pelo sindicato operário; ou mista, se direta em parte e, em parte, indireta.

- Quanto à ocasião - pode ser imediata, se entregue ao empregado no momento mesmo de sua distribuição, ou diferida, se a entrega fôr condicionada a prazo ou condição, podendo ainda aqui haver dualidade, isto é, parte entregue desde logo e parte em época posterior.

- Quanto aos sujeitos de participação - será individual, se feita ao empregado isoladamente, ou coletiva, se entregue in solidum à totalidade dos empregados ou ao seu sindicato. Ainda quanto aos sujeitos, pode ser parcial, se atribuída apenas a um grupo de empregados, ou universal, se concedida a todos os dependentes da emprêsa. ${ }^{11}$

- Quanto à modalidade de distribuição - pode ser pecuniária, se entregue em dinheiro, ou acionária, se ao empregado fôr conferida sob a forma de ações ou cotas-partes do capital.

EVOLUÇÃO

\section{A. Participação nos Lucros - Liberalidade}

Nas emprêsas privadas a participação nos lucros começou - quase na metade do Século XIX, em França como ato de liberalidade de empregadores. Assim, na França temos em 1842 o exemplo pioneiro de EDMÉ-JEAN LECLAIRE e em 1868 o de GodIN; na Inglaterra o de Briggs, em 1865; na Alemanha, em 1854, o da Companhia de Produtos Quimicos de Thann e Mulhouse, etc...

11) Pontes de Miranda, Tratado de Direito Privado, Borsoi, Tomo XLVII, pág. 204. 
Em todos êsses casos trata-se de liberalidade do empregador, se bem que não desinteressada. Assim, a LECLAIRE se atribuiu, além de intuitos paternalistas, a intenção, que foi a mesma de seus seguidores, de suprir a dificuldade de fiscalização do trabalho dos empregados de sua emprêsa de pinturas, despertando-lhes o interêsse por maior produtividade e economia de materiais. Esses intentos confundem a participação nos lucros com o salário-incentivo. Com efeito, embora aquêles resultados possam provir da aplicação da participação nos lucros, não constituem êles a sua verdadeira finalidade. ${ }^{13}$

Na legislação prevêem a possibilidade de atribuição facultativa de lucros aos empregados:

- o Código Civil Italiano, nos arts. 2 099, 2. ${ }^{a}$ parte ("Retribuição - O prestador de trabalho pode também ser retribuído, no todo ou em parte, com participação nos lucros ou nos produtos, com porcentagens ou com prestações em natureza") e 2102 ("Participação nos lucros - Se o acôrdo não dispuser diversamente, a participação nos lucros que cabe ao prestador de trabalho é determinada à base dos lucros líquidos da emprêsa e, para as emprêsas submetidas à publicação de balanços, à base dos lucros líquidos resultantes do balanço regularmente aprovado e publicado");

- a lei espanhola de contratos de trabalho, nos arts. 44 e 45, e o art. 26 do "Fuero de los Españoles";

- em Portugal o art. 15 do Estatuto do Trabalho Nacional (Decreto n. 23 048, de 23 de setembro de 1933) e 0 art. 6. $.^{\circ} \S 1 .^{\circ}$, da Lei n. ${ }^{\circ} 1952$, de 10 de março de 1937.

\section{B. Participação nos Lucros - Obrigação Legal}

Vários países introduziram no Século XX em seu ordenamento legal a obrigatoriedade da participação nos lu-

12) Para o histórico da participação nos lucros vidé obra citada na nota 3.

13) Carlos Maria Londoño, La Participación de los trabajadotes en los beneficios de la empresa, Madri: Rialp, 1962, pág. 24 e cap. 8. 
cros: Bolívia, Brasil, Chile, Colômbia, Equador, França, Irã, México, Peru e Venezuela.

- Bolívia - A Constituição de 1945, no art. 127, determinou o estabelecimento da participação nos lucros pela lei. Esta, de 22 de novembro de 1945, manda as emprêsas comerciais e industriais distribuírem até $25 \%$ dos lucros, no máximo.

- Brasil - No Brasil (o caso brasileiro estudaremos melhor adiante) o n. ${ }^{\circ}$ IV do art. 157 da Constituição de 18 de setembro de 1946 determina que a legislação do trabalho deve obedecer ao preceito de "participação obrigatória e direta do trabalhador nos lucros da emprêsa, nos têrmos e pela forma que a lei determinar". Essa lei ainda não existe.

- Chile - No Chile a participação nos lucros está regulada pelos arts. 146 a 151 do Código do Trabalho de 1931, modificado por diversas leis posteriores. Em realidade, concedem, pràticamente, uma gratificação anual, que é, no máximo, de 3 meses de salário, isto é, $25 \%$ do salário anual, ou então, $20 \%$ dos lucros anuais, à escolha do empregador .

- Colômbia - Nesse país a participação nos lucros foi substituída por uma prima de servicios ou prima anual, consagrada pelo art. 320 do Código Substantivo do Trabalho (Dec. n. ${ }^{\circ} 2$ 663, de 5 de agôsto de 1950).

- Equador - A lei de 2 de dezembro de 1948 estabelece a participação líquida individual dos trabalhadores, nos lucros das respectivas emprêsas, de $7 \%$ (art. $2 .^{\circ}$ ).

- França - Lei de 26 de abril de 1917 previu nova forma de sociedade por ações, que comportaria ações ordinárias e ações de trabalho, mas que não foi realizada. Daí que sòmente muito mais tarde a Ordenação n. ${ }^{\circ} 59126$, de 7 de janeiro de 1959, seguida dos decretos de aplicação, de 29 de agôsto de 1959 e 20 de maio de 1960, fizesse uma tentativa para transformar o contrato de trabalho e ¿ proxiná-lo do contrato de sociedade. Procura ela desen- 
volver a colaboração entre o capital e o trabalho. Entre outras medidas, a participação dos trabalhadores nos lucros das emprêsas é incentivada, não apenas com a declaração expressa de que ela não se incorporará à remuneração para nenhum dos efeitos ( $\operatorname{art.} 4 .^{\circ}$ ), como também pela possibilidade da dedução de seu valor das bases de impostos para fixação do impôsto sôbre as sociedades ou sôbre a renda das pessoas naturais. Se a participação consistir em emissão ou distribuição de ações em favor dos trabalhadores, as operações correspondentes ficarão isentas das contribuições e direitos que normalmente lhes são impostos, tudo no máximo de três anos. BRUN e GALLAND consideram modestos os seus resultados. ${ }^{14}$

- Irã - Decreto de 7 de janeiro de 1963 obriga as emprêsas industriais e de produção sujeitas à legislação do trabalho a celebrarem convênios coletivos de trabalho para a concessão de prêmios ou de participação nos lucros líquidos, cuja taxa será determinada pelo Ministério do Trabalho e de Assuntos Sociais. A distribuição entre os trabalhadores levará em conta os fatôres antiguidade e salário.

- México - Decreto de 20 de novembro de 1962 reformou o art. 123 da Constituição Política dos Estados Mexicanos, de $1 .^{\circ}$ de maio de 1917 , que regula a legislação do trabalho. Suas frações VI e IX garantiam aos trabalhadores o direito à participação nos lucros. Aquêle decreto alterou a fração IX, regulamentando a sua aplicação. Em conseqüência, foram reformados também os artigos correspondentes da Ley Federal del Trabajo (arts. 100-B a $100-U$ e $428-I$ a $428-Y$ ). O valor da porcentagem a ser distribuída é fixado pela Comissão Nacional para a Participação dos Trabalhadores nos Lucros das Emprêsas. ${ }^{15}$

14) A. Brun e H. Galland, Droit du Travail (Mise à Jour), Paris: Sirey, 1962, pág. 172.

15) Alberto Trueba Urbina e Jorge Trueba Barrera, Ley Federal del Trabajo Reformada y Adicionada, México: Parma, 1963, passim. 
- Peru - O Decreto n. 10 908, de 3 de dezembro de 1948 , estabeleceu a participação nos lucros à base de $30 \%$ dos lucros líquidos, fazendo-se a distribuição proporcionalmente a remuneração, antiguidade, assiduidade e eficiência .

- Venezuela - O art. 87 da nova Constituição kia Venezuala, de 23 de janeiro de 1961 , determina que a lei fixará a participação que deve corresponder aos trabalhadores nos lucros das emprêsas. Anteriormente, a Lei do Trabalho, de 4 de maio de 1945 , nos arts. 72 a 92, já regulava a participação nos lucros. Tôda a emprêsa é obrigada a distribuir $10 \%$ dos lucros líquidos anuais entre os trabalhadores. Não pode, porém, a parte individual do trabalhador ser superior ao salário de dois meses.

\section{OBJEÇÕES}

São numerosas as objeções apresentadas contra a participação nos lucros, em primeiro lugar - et pour cause... - pelos empresários; em segundo, por alguns autores, e, em terceiro, até mesmo por sindicatos de trabalhadores.

\section{A. Objeções Patronais}

- A estrutura capitalista seria incompatível com a participação nos lucros - Afirma-se, inicialmente, a incompatibilidade entre a estrutura capitalista e a participação nos lucros. Ora, tal incompatibilidade não existe.

A estrutura capitalista de nossa economia baseia-se na existência do direito de propriedade privada e no princípio da livre iniciativa (Constituição Federal, arts. 145 e segs.), princípios conservados no sistema da participação acionária nos lucros.

Mantém-se a propriedade privada da emprêsa, com a única diferença de que, em lugar de ela caber apenas aos "atuais" proprietários, passa a caber também a seus empregados. 
Conserva-se outrossim a livre iniciativa, pois a "cooperativa de produção", em que se transforma aproximadamente a emprêsa, age integralmente no regime de livre emprêsa, pois não deixa de ser regida pelas leis que regulam sociedades anônimas e sociedades por cotas de responsabilidade limitada.

- Do risco empresário decorreria o direito à totalidade dos lucros - Afirma-se que "apenas o empreendedor assume o risco", escapando inteiramente o trabalho ao "risco empresário" que "justifica a pertinência do lucro ao empreendedor". ${ }^{16}$

Ora, por um lado, como nem sempre o empresário inverte na emprêsa todo o seu patrimônio, em caso de perda total a sua situação é melhor que a do trabalhador. Com efeito, para êsse, normalmente, o trabalho na emprêsa é meio de subsistência própria e de sua família, e a perda do emprêgo significa, pelo menos momentâneamente, ruína completa.

Por outro, já do vetusto Código Comercial de 1850 consta a sociedade de capital e indústria, na qual o sócio de indústria, que entra apenas com o seu trabalho, participa dos lucros, mas não das perdas. Leiam-se os arts. 321 e 322: "O sócio de indústria não responsabiliza o seu patrimônio particular para com os credores da sociedade. Se, porém, além da indústria, contribuir para o capital com alguma quota em dinheiro, bens ou efeitos, ou fôr gerente da firma social, ficará constituído sócio solidário em tôda a responsabilidade."; "O sócio de indústria não é obrigado a repor, por motivos de perdas supervenientes, o que tiver recebido de lucros sociais nos dividendos; salvo provando-se dolo ou fraude de sua parte."

Logo, o fato de o trabalhador não participar das perdas não pode ser impedimento de que êle participe dos lucros.

- A participação nos lucros provocaria a descapitalização Argumenta-se que as emprêsas têm necessidade de re-

16) Alberto Pasqualini, Bases e Sugestóes para uma Política Social, Rio de Janeiro: São José, 1958, pág. 157. 
investir os lucros obtidos ou boa parte dêles (autofinanciamento) e que a participação nos lucros o impediria . Nesse sentido se pronunciou o Conselho Nacional de Economia. ${ }^{17}$

A parte dos lucros atribuível aos trabalhadores é raramente superior a $30 \%$. Logo, não impediria totalmente o autofinanciamento. Por outro lado, a participação nos lucros acionária favorece exatamente a desejada reinversão dos lucros atribuídos aos trabalhadores. Além disso, obriga o próprio empresário a reinvestir para não perder o contrôle da emprêsa.

- O pequeno valor da participação nos lucros exasperaria os trabalhadores - A quem observe balanços de emprêsas publicados pela imprensa não há de parecer que seus lucros sejam assim tão baixos... Com as atuais medidas de correição monetária (reavaliação de ativos, etc.) também não mais se pode falar que, em face da inflação, tais lucros seriam fictícios.

Exemplificaríamos com a Willys Overland do Brasil S. A.. Contando, em outubro de 1963, com 9402 empregados, teve um lucro líquido de Cr\$5858000 000. Se a participação nesses lucros fôsse de apenas $25 \%$, receberiam êsses empregados Cr $\$ 1464500000$. Se a divisão entre êles fôsse igualitária, cada um teria direito a Cr\$155 764, quantia superior ao salário médio na emprêsa, que foi de Cr\$145 500. Observa-se ainda que, referindo-se ao exercício sôbre o qual versou a publicação, afirma a diretoria daquela emprêsa: "Não escapando a todos êsses fatôres adversos, a indústria automobilística também registrou um declínio em seu volume de produção em 1963, quando produziu 174207 unidades, contra 190971 unidades em 1962." Isso não obstante, afirma também: "Na assembléia geral extraordinária realizada em 27 de fevereiro de 1964 foi autorizada a distribuição de bonificação ern ações, resultante do aumento de capital então aprovado, em vir-

17) "Conselho Nacional de Economia", parecer na Revista do Conselho Nacional de Economia, Rio, 1955, n.* 33. 
tude do que os Senhores Acionistas estão recebendo uma nova ação de Cr\$1 1000 para cada ação de Cr\$1000 já possuída. Assim, a correção do valor nominal do investimento, realizada no decorrer do último exercício, foi bastante apreciável, resultando que os Senhores Acionistas possuem agora 2 ações novas de $\mathrm{Cr} \$ 1000$, ou seja, Cr\$ 2000 , no lugar de cada lote de 5 ações antigas de Cr\$ 170 , no total de $\operatorname{Cr} \$ 850$, que possuíam no início do exercício. Convém ressaltar, ainda, que no mesmo período esta companhia distribuiu também dois dividendos em dinheiro: um, em novembro de 1963, de $6 \%$, correspondente ao semestre de julho a dezembro de 1962, e outro, em maio de 1964 , de $8 \%$, correspondente ao ano de 1963." 18 Nada mais é preciso acrescentar.

A participação nos lucros levaria os capitalistas nacionais a investirem em atividades mais rendosas e menos produtivas e afastaria os capitais estrangeiros - A escolha de atividades em que investir capitais não depende exclusivamente do arbítrio dos investidores, mas das condições dos mercados. E nestes as atividades menos produtivas, òbviamente, dão lucros menores. Destarte, a diferença entre os resultados dos dois tipos de atividades - com e sem participação nos lucros - raramente será a favor dos últimos.

Por outro lado, também não é arbitrária a escolha dos mercados onde investir. A simples existência da participação nos lucros num bom mercado, como, por exemplo, o Brasil, não seria suficiente para afastar os capitais estrangeiros.

- A participação nas lucros seria inflacionária - A participação nos lucros, determinando maior poder aquisitivo dos trabalhadores, sem correspondente aumento de produção, favoreceria maior procura dos bens de consumo, aumentando a inflação.

Preliminarmente, a objeção só se aplica à participação pecuniária, pois a forma acionária não merece a censura, dada

18) Cf. publicação no $O$ Estado de São Paulo de 18-10-1963, págs. 10 e 11. 
a sua capitalização, ou seja, exatamente o contrário: inversão em bens de produção e não em bens de consumo. Ademais, não é exato que a participação nos lucros deixe de causar qualquer aumento na produtividade dos empregados que a recebem.

- A participação nos lucras seria injusta para os trabalhadores de emprêsas pouco lucrativas - Há emprêsas com muitos trabalhadores e pouco lucro, como as de serviços públicos, e outras em que ocorre o inverso. Para estas se deslocariam os empregados daquelas, injustiçados com parca ou nenhuma participação.

Em primeiro lugar, tal deslocamento é impossível, pois cada emprêsa necessita número limitado de empregados. Em segundo, seria maior essa injustiça que a decorrente de nenhum trabalhador participar nos lucros da "sua" emprêsa?

Ademais, seria viável a criação, por lei, de um "Fundo de Participação nos Lucros", ao qual se destinasse, por exemplo, o excesso verificado em algumas emprêsas, para ser distribuído entre aquelas em que houvesse carência. Nada nos parece tão certo como o princípio consagrado no artigo 130 da Constituição de 1937: "O ensino primário é obrigatório e gratuito. A gratuidade, porém, não exclui o dever de solidariedade dos menos para com os mais necessitados."

- Participação nos lucros produziria redução dos salários - Diz-se que aos empregados sòmente interessa o salário real e não uma ilusória participação nos lucros. Sem dúvida, se por participação nos lucros se entender tão-sòmente a "concessão de abonos, acréscimos periódicos a salários", que "não têm nada em comum com a participação nos lucros pròpriamente dita", é óbvio que ela não poderá interessar aos empregados. Mas não é isso o que propomos.

Nenhum valor tem a objeção de que a participação obrigatória nos lucros produziria redução dos salários, tirando ao empregador o ânimo de aumentá-los espontâneamen- 
te. Em realidade, êsse ânimo existe raramente e os aumentos de salário se produzem, na quase totalidade dos casos, em conseqüência de mandamentos legais ou de pressões dos empregados, muitas vêzes através de greves, que provocam acréscimos decorrentes de contratos coletivos de trabalho ou de sentenças normativas da Justiça do Trabalho. E evidente - ao contrário do que se procura assoalhar - que, tornando-se os empregados acionistas ou cotistas das emprêsas para as quais trabalham, isso em nada influiria na sua condição de empregados. Com efeito, as suas relações com a emprêsa naquela qualidade serão regidas pelas leis comerciais, e nesta pelas leis sociais. Nenhum motivo há, pois, para que possam, como empregados, sofrer qualquer prejuizo, inclusive quanto a salários.

\section{B. Objeções Doutrinárias}

Alberto Pasqualini apresentou objeções à participação nos lucros, nestes têrmos: "Contra a participação direta há, pelo menos, três objeções fundamentais: a) dificuldade quase insuperável de estabelecer o critério de sua fixação; b) exclusão do benefício, dos empregados de emprêsas que, eventualmente, não produzam lucros; c) exiguiidade do benefício e conseqüente desinterêsse do trabalhador pela sua percepção." ${ }^{19}$ Já examinamos as duas últimas objeções. Analisaremos, portanto, apenas a primeira.

- Dificuldade no critério de fixação da participação nos lucros - Afirma PAsqualini: "A dificuldade começa no fixar a noção de lucro. Deve ser êle conceituado como o considera a legislação do impôsto sôbre a renda, ou devem ser deduzidos outros valôres antes de ser apurada essa expressão residual? Por exemplo, entre as deduções deverse-á incluir uma parcela correspondente aos riscos do negócio? E também o juro do capital? Certamente essas deduções não devem estar fora das cogitações dos empregadores. Mas, fixado ou caraterizado o lucro para o efeito da participação, qual deverá ser o critério de sua dis-

19) Cf. nota 16 . 
tribuição entre o capital e o trabalho? E como se repartirá entre as diferentes categorias de empregados e trabalhadores da emprêsa a cota de lucro que lhes é deferida? À primeira vista poderia parecer justo que a distribuição individual se fizesse em proporção à contribuição de cada um na produção do lucro. Como, porém, determinar o critério diferenciativo ou o coeficiente dessa contribuição? Poder-se-ia estabelecer como bases o salário, a assiduidade, o tempo de serviço, a produtividade, a eficiência. Seriam critérios realmente equiitativos? Além disso, como apurar, por exemplo, a produtividade? Há, ainda, outras dificuldades. A relação entre a fôlha de salários e o capital varia muito de emprêsa para emprêsa, dependendo da natureza desta." 20

Ora, parece-nos fácil responder a essas objeções. Se os fatôres de produção (excluído o Estado) são quatro, uma divisão eqüitativa dará aos trabalhadores da emprêsa $25 \%$ dos lucros líquidos e $75 \%$ aos demais fatôres (todos representados pelo empresário ou pelo capital). E evidente que nesses $3 / 4$ dos lucros já estão incluídos uma parcela correspondente aos riscos do negócio e também o juro do capital. Porque deduzi-los de nôvo? E, quanto aos lucros, que impede sejam os declarados e reconhecidos pela fiscalização do impôsto de renda?

Consideremos agora a objeção que não admite um valor único para a cota global de participação dos trabalhadores, sob a alegação de que a relevância do trabalho (de execução) dêles varia conforme o tipo de emprêsa. Numas, mais automatizadas ou mais dependentes do trabalho de direção do empresário, deveria preponderar o capital sôbre o trabalho. Noutras, exatamente o contrário. Mas, para isso existem fórmulas, desde a proposta por EINAUDI, que atendem a essas diferenças, levando em conta, no cálculo daquela cota, tanto o valor do capital (ou de seus juros), como o do trabalho representado pelos salários. ${ }^{21}$

20) Cf. nota 18 .

21) Luigi Einaudi, Lezioni di Politica Sociale, Turim: Eunaudi, 1950, pág .141. 
Por outro lado, a fixação do valor individual da participação nos lucros é pràticamente pacífica. Não deverá ser igualitária, mas atender a coeficientes numéricos, fàcilmente adotáveis, referentes aos salários, à assiduidade e ao tempo de serviço. Quanto à produtividade (apreciável também numèricamente) ou à eficiência, que também deveriam ser consideradas, nada impede sejam atribuídas pelo empresário, seu melhor juiz .

\section{Objeçōes dos Sindicatos Operários}

O já citado BIRNIE narra o seguinte: "Afora o antigo exemplo de participação nos lucros pôsto em prática, em 1829, nas propriedades irlandesas de Lord Wallscourt, o primeiro plano organizado de participação nos lucros, na Inglaterra, teve início em 1865, nas minas de carvão dos Briggs, de Yorkshire. Nesse ano os Briggs, cujas relações com os operários não eram muito amistosas, transformaram a emprêsa em sociedade anônima, convidando os empregados a comprar ações. Resolveram posteriormente, sempre que os lucros excedessem $10 \%$, dividir metade do excesso com os empregados sob a forma de bonificação, além dos dividendos pagos por fôrça das ações. Quatro anos mais tarde permitiram que um representante dos operários-acionistas tivesse assento na diretoria. O plano vigorou por cêrca de 10 anos e, durante todo êsse tempo, as bonificações pagas aos trabalhadores montaram somas bem regulares, atingindo a média de cêrca de $9 \%$ dos respectivos salários. $O$ tracasso final do experimento resultou da hostilidade dos Briǵs ao sindicalismo. Esperavam êles que os operários abandonassem o sindicato em troca dos benefícios do plano de participação nos lucros. A princípio, muitos assim agiram, mas quando, em 1872, os preços do carvão subiram e os mineiros de tôda a Inglaterra receberam aumentos salariais os trabalhadores começaram a voltar para o sindicato. Verificou-se em 1874 uma greve geral em que os empregados dos Briggs tomaram parte. Em consequiência disso, o plano de participação nos lucros foi cancelado no ano seguinte. No princípio o plano foi muito 
bem aceito. Mill e outros líderes da opinião pública passaram a elogiá-lo como sendo o marco inicial de uma nova era nas relações industriais, e foram terríveis o desapontamento e a desilusão causados pelo seu fracasso, ao mesmo tempo em que a atitude adotada pelos Briggs em face do sindicalismo teve o infeliz efeito de gerar nas classes trabalhadoras forte desconfiança contra a participação nos lucros, o que nunca se conseguiu extirpar completamente." ${ }^{22}$ (Grifos nossos.)

Assim, em 1923 e em 1925 o British Trade Union Congress condenou a participação acionária nos lucros como "destinada a desencaminhar trabalhadores e evitar a solidariedade dos sindicatos". Os trabalhadores organizados e seus líderes viam na técnica da participação nos lucros expediente político para evitar a solidarização dos empregados em suas unióes e sindicatos, disfarce para manter baixos os salários, e proposta de igualação dos empregados para atenuar as diferenças entre êles no tocante a qualidades pessoais. ${ }^{23}$

Ora, a participação nos lucros com a conversão de seu valor individual em cotas-partes do capital da emprêsa para seus empregados contribui bastante para a solução da Questão Social porque os leva à copropriedade dela, transformando-os em sócios do empregador, faz com que êles passem a ter, em grande parte, os mesmos interêsses que êle, transmudando, assim, a emprêsa, de instrumento muitas vêzes usado para exploração do trabalho subordinado, em organismo semelhante às cooperativas de produção.

Com efeito, a "eterna luta dos ricos e dos pobres" irá desaparecendo à medida que, graças à conversão das cotas de participação em cotas do capital das emprêsas, os ricos forem ficando menos ricos e os pobres menos pobres. E é por isso mesmo que os interessados na continuação e no agravamento da luta de classes combatem a participação nos lucros.

22) Cf. nota 3.

23) J. A. C. Brown, La Psicologia Social en la Industria, México, Fondo de Cultura, 1958, pág. 230. 
D. Fracasso em outros países? - Alega-se que a participação nos lucros obrigatória fracassou em todos os países em que foi instituída.

Ora, isso não é exato, pois, conforme já vimos, a participação nos lucros nêles existente é meramente pecuniária e em muitos dêles não passa de mera gratificação anual de 1 ou 2 salários (Venezuela), tendo às vêzes até o nome de prima de servicios (Colômbia). Ora, isso não é a verdadeira participação nos lucros. Não obstante, no México a participação nos lucros, mesmo pecuniária, deu esplêndidos resultados. Quem o diz é o seu presidente: “' $A$ economia mexicana experimentou em 1964 uma expansão que sòmente tem precedentes nos sombrios periodos bélicos.' O Presidente Adolfo Lopez Mateos fêz tal assertiva esta semana, ao Congresso Federal, em seu informe sôbre as atividades do País nos últimos doze meses. O mandatário traçou um amplo programa da expansão do País e do desenvolvimento de sua indústria e de sua agricultura, que permitiram alcançar para todos os mexicanos um melhor nível de vida. Lopez Mateos salientou que a agricultura, a indústria e os serviços cresceram com índices desusados, mercê da paz política, da estabilidade cambial, da fixação de maiores salários-mínimos e da aplicação da nova politica de distribuição de lucros"; e: "A bonança geral causada por êsse desenvolvimento econômico acrescentou-se, para a população trabalhadora do País, à primeira aplicação da lei de distribuição de lucros, cujos efeitos, salientou o mandatário, foram manifestos no progresso geral. Lopez Mateos assinalou que cêrca de 900 milhões de pesos (72 milhões de dólares) foram distribuídos aos trabalhadores mexicanos, como resultado do exercício de 1963, a título de participação nos lucros das emprêsas." 24 (Grifos nossos.)

Como se viu, quase tôdas as objeções apresentadas referem-se à participação pecuniária, não à participação acionária, contra a qual elas não procedem absolutamente.

24) "Participação nos lucros firmou economia mexicana", Fôlha de São Paulo de 6-9-1964. 
Na maioria resultam da confusão entre o salário-incentivo e a verdadeira participação nos lucros, que, em realidade, nada tem que ver com êle, pois dêle diverge em natureza e em finalidade.

VANTAGENS DA PARTICIPAÇÃO NOS LUCROS

\section{Vantagens da Participação nos Lucros em Geral}

As respostas que demos às principais objeções contra a participação nos lucros evidenciam, por si mesmas, as vantagens do sistema.

A participação nos lucros cria entre empregador e empregados de u'a mesma emprêsa, na forma por nós proposta, a affectio societatis, obedecendo assim aos mandamentos das encíclicas sociais, notadamente da Quadragesimo Anno e da Mater et Magistra. Dando ao empregado o caráter de sócio da emprêsa, exalta-lhe a qualidade de pessoa humana e diminui a desigualdade ora existente entre auto-suficientes e hipo-suficientes.

Todos os teóricos do capitalismo reconhecem ser o interêsse pessoal fator eminente de produtividade. Porque haveria de sê-lo tão-sòmente o interêsse pessoal do empregador e não o dos empregados, uma vez desaparecida a oposição entre êles?

Sem dúvida alguma os empregados, sabendo que são coproprietários da emprêsa e que, portanto, trabalham não exclusivamente para enriquecer o empregador, mas também em proveito próprio, irão fazê-lo com mais interêsse, procurarão poupar o maquinismo e economizar a matéria-prima, pois o estarão fazendo igualmente pro domo sua.

\section{Vantagens da Participação Obrigatória e Acionária}

As vantagens acima se acentuam quando a participação nos lucros não é apenas mera liberalidade do paternalismo patronal, mas um reconhecido direito dos trabalhadores. Assumindo a forma acionária, essas vantagens ainda mais se acrisolam. 
Reconhecemos que o sistema por nós proposto jamais foi experimentado. Mas, por que não o poderíamos fazer? Por que haveremos de ser sempre caudatários de outros países? Nem se diga que, sendo nós um país subdesenvolvido, devemos cogitar mais de produzir que de distribuir.

O sistema que preconizamos não efetua a distribuição note-se bem - senão da propriedade dos meios de produçâo, sem estatizá-los, não contribuindo, assim, para incrementar a inflação, mas, muito ao contrário, para diminuí-la, pois o aumento da produção é um dos melhores meios de combatê-la, sabido que a participação nos lucros aumenta a produtividade dos empregados.

\section{A Participação nos Lucros Acionária e a Democratização do Capital}

Muito se fala presenternente em democratização do capital. O próprio Presidente CASTELlo BRANCo assim se manifestou: "Não há dúvida de que caminhamos ràpidamente para a democratização das emprêsas, fenômeno por alguns denominado de neocapitalismo ou capitalismo democrático e, em que pêse às transformações por que deverá passar quando transplantado para o nosso meio, não é temerário adiantar que conservará os traços fundamentais." ${ }^{25}$ Nessa ordem de idéias o Dec. n. ${ }^{\circ} 54$ 105, de 6 de agôsto de 1964, criou o Fundo de Democratização do Capital das Emprêsas. Dará prioridade às solicitações das emprêsas que aceitem fórmulas que envolvam a abertura de seu capital social (art. $4^{\circ}$, parág. único, letra a).

Ora, a participação nos lucros acionária é a melhor e, em nosso meio, talvez a única forma de democratização do capital. Experiências nos Estados Unidos já o têm demonstrado. Assim, o Presidente do Clube dos Lojistas do Rio de Janeiro afirma que os norte-americanos, "com o mesmo entusiasmo com que outrora se decidiram a promover a democratização do capital das emprêsas, para melhor

25) Notícia divulgada pela Fôlha de São Paulo de 18-10-1964. 
acelerar o desenvolvimento dos negócios, dedicam-se agora a incrementar a participação nos lucros das emprêsas, a fim de conseguirem mais apoio da fôrça de trabalho a seus emprendimentos, promovendo o progresso e o lucro dêsse progresso para todos". Afirma, a seguir, que a "nova tendência de transformar empregados em empregados-acionistas, através da democrática coparticipação nos lucros, cresce dia a dia" e que "mais de 80 mil firmas norte-americanas, empregando acima de 5 milhões de pessoas, desenvolveram planos de participação nos lucros". Êsses fundos, segundo o presidente do Clube dos Lojistas, são distribuídos por um Fundo de Participação para êsse fin constituído no âmbito da emprêsa e para o qual convergem não só determinada percentagem dos lucros anuais da emprêsa, que varia entre 10 e 25 por cento, mas também pequena parcela do salário dos empregados. Como exemplo dêsses fundos de participação cita os da Walǵreen Co., cadeia de 472 drugstores, num montante de $\mathbf{4 0}$ milhões de dólares, e o da Dominion Foundry and Steel Co., do Canadá, de $\mathbf{4 5}$ milhões de dólares, valor que representa o dôbro do que era há cinco anos. ${ }^{26}$

\section{A PARTICIPAÇÃo NOS LUCROS NO BRASIL}

O estudo da participação nos lucros no Brasil compreende três fases: a) antes da Constituição de $1946 ; b$ ) na Constituição de 1946; e c) após a Constituição de 1946.

\section{A. A Participação nos Lucros antes da Constituição de 1946}

Mesmo antes da Constituição de 1946 houve referência à adoção da participação nos lucros, constantes de manifes-. tações doutrinárias, congressos e projetos de lei. $\mathrm{Na}$ legislação houve apenas ligeiras referências à participação nos lucros contratual.

26) "Progresso depende de democratização", no Correio da Manha (Rio), de 21-6-1964. 
- Manifestações doutrinárias — RUY BARBosA, já em 1919, assim se exprimia: ". . . precisamos ensaiar a associação do capital com o trabalho, tão desenvolvida, vai por um quarto de século, na Grã-Bretanha, onde há seis anos já o praticavam cento e quarenta casas inglêsas, nas quais os operários, em número de cento e seis mil, eram acionistas com os patrões, explorando, com êstes, um capital de trezentos milhóes de libras".

- Congressos - Manifestaram-se favoràvelmente à participação nos lucros a Carta Econômica de Teresópolis (1945), a Carta de Paz Social (pela participação nos lucros indireta), o II. ${ }^{\circ}$ Congresso Brasileiro de Direito Social e o Congresso Sindical dos Trabalhadores, todos de 1946, e o Congresso Brasileiro dos Trabalhadores na Indústria (1949) .

- Projetos - Em 1919 houve o projeto dos deputados Deodato Maia, Antônio Carlos e Borges de MedeIRos. Em 1936 o de OsWALdo de LIMA, FlôRes DA Cunha e Adroaldo Mesquita. Em 1922 o Presidente ARTHUR BERNARDES se referiu ao assunto em sua mensagem ao Congresso.

- Legislação - A única referência legislativa era a do art. 63 da Consolidação das Leis do Trabalho, verbis: "Não haverá distinção entre empregados e interessados, e a participação em lucros ou comissões, salvo em lucros de caráter social, não exclui o participante do regime dêste capítulo."

\section{B. A Participação nos Lucros na Constituição de 1946}

Foi a Constituição de 1946 que, pela primeira vez, se referiu expressamente à participação nos lucros, ao dispor no art. 157, e seu n..$^{\circ}$ IV: "A legislação do trabalho e da previdência social obedecerão aos seguintes preceitos, além de outros que visem à melhoria da condição dos trabalhadores [ . . ] IV - participação obrigatória e direta do trabalhador nos lucros da emprêsa, nos têrmos e pela forma que a lei determinar". 
C. A Participação nos Lucros após a Constituição de 1946

- Câmara dos Deputados - Após a Constituição de 1946 foram apresentados numerosos projetos tendentes a regular o preceito constitucional. Foram êles: n. ${ }^{\circ}$ 96/46, Bertho Condé, n. ${ }^{\circ} 104 / 46$, Segadas VianNa, n. ${ }^{\circ}$ 5/47, DaNiel Faraco; n. ${ }^{\circ}$ 537/47, JoÃo Amazonas e n. ${ }^{\circ} 144$ / 51, ARTHUR AUDRÁ. Todos êsses projetos foram reunidos no Substitutivo n. ${ }^{\circ} 1039 / 48$, de autoria do deputado Paulo Sarasate. Êste, depois de sofrer várias emendas, foi afinal aprovado pela Câmara dos Deputados, sendo remetido ao Senado Federal onde tomou o n. ${ }^{\circ} 333 / 52$, como projeto vindo da Câmara dos Deputados.

\section{- Análise do Projeto n. 1 039/48 (333/52):}

1) Campo de aplicação - $\mathrm{O}$ projeto abrange tôdas as emprêsas privadas de fins lucrativos, com exceção das rurais e das de propriedade da União, dos Estados ou Municípios, salvo quando tal propriedade ou administração estatal seja transitória. São consideradas emprêsas autônomas as filiais, sucursais, agências e mais estabelecimentos dependentes que, escriturando capital e lucros e perdas próprias, fazem declaração à parte da emprêsa principal. Provada a dissociação de um mesmo grupo comercial ou industrial em várias emprêsas ou a alteração jurídica de sua estrutura, com o fim de diminuir os lucros de uma ou de algumas dentre elas, elidindo os objetivos da participação, poderá a Justiça do Trabalho, a requerimento dos interessados, determinar que, para os efeitos dessa lei, as emprêsas constantes do grupo sejam consideradas como uma só.

Só participarão dos lucros os empregados cujos contratos de trabalho, em sua duração, tenham abrangido todo o exercício a que tais lucros se refiram, salvo se, tendo mais de um ano de trabalho efetivo, demitir-se ou fôr dispensado antes do encerramento do exercício financeiro a que tais lucros se refiram, exceto em caso de improbidade comprovada. 
Não têm direito à participação nos lucros, além dos empregados das emprêsas acima excluídas, os domésticos e os servidores públicos e autárquicos ou de entidades paraestatais.

É extensiva a participação nos lucros aos que, embora sem a relação de emprêgo, exerçam efetivamente atividade pessoal na emprêsa, excluídos os diretores de sociedades anônimas.

2) Capital - Capital é a soma de capital realizado, reservas e provisões (salvo as que se destinem a atender depreciações ou outras eventuais reduções do ativo) e importâncias menores ou iguais à soma dos primeiros, mantidas pelos titulares ou sócios da emprêsa, em poder desta, durante pelo menos dois anos, excluídos os juros.

O capital das emprêsas estrangeiras será constituído do capital estrangeiro, originário de acionistas, que tenha sido efetivamente aplicado na emprêsa, no território nacional, e dos lucros tributados que tenham sido incorporados ao capital ou escriturados como reservas ou provisões, excluídas as destinadas expressamente a atender depreciações ou outras eventuais reduções do ativo.

3) Lucros - São os tributáveis pela legislação do impôsto de renda, deduzidos: I) o montante do impôsto de renda, excluídas as multas; II) os juros de $8 \%$ sôbre o capital da emprêsa para remuneração dêste; III) as quantias correspondentes ao aumento do valor do ativo, resultante de vendas ou reavaliações efetuadas no respectivo exercício: a) dos imóveis utilizados pela emprêsa para alojamento de seus serviços e instalações; $b$ ) da maquinaria utilizada pela emprêsa para a produção de bens do seu ramo de negócio; IV) a importância necessária à amortização de prejuízos verificados nos três últimos exercícios, até o máximo de $30 \%$ dos lucros acima.

4) Valor global - Dos lucros apurados na forma acima a emprêsa distribuirá entre seus empregados parcela não inferior a uma fração cujo numerador será o total dos salários pagos durante o ano e a êle referentes, inclusive o 
pagamento de horas extraordinárias, e cujo denominador será êsse total acrescido de capital (definido acima), ou

seja: VG pnl $=\frac{\mathrm{S}}{\mathrm{S}+\mathrm{C}}$. Êsse valor terá como limite

mínimo $1 / 10$ do total dos salários. Se resultar inferior, será aumentado até atingir êsse limite mínimo, se não exceder $20 \%$ dos lucros. Em conseqüência, o mínimo da participação nos lucros é ou 1/10 do total anual dos salários, ou $20 \%$ dos lucros apurados. Se fôr superior a $20 \%$, não será alterada até atingir $40 \%$ - limite máximo da participação nos lucros obrigatória, dado também pela metade dos salários pagos no exercício, inclusive horas extraordinárias.

As emprêsas estrangeiras sem capital destinado à aplicação no território nacional distribuirão $1 / 4$ do total anual dos salários, se êle fôr igual ou inferior a $30 \%$ dos lucros tributáveis pela legislação do impôsto de renda, deduzidos êsse impôsto e o necessário para amortização dos prejuízos dos últimos três exercícios.

5) Valor individual - O valor individual da participação nos lucros será determinado através de planos elaborados livremente, por acôrdo, pela emprêsa e 2/3 dos seus empregados; ou então pela emprêsa, observados o critério obrigatório do salário anual de cada empregado, incluindo-se horas extraordinárias e a sua antiguidade, e, facultativamente, os critérios de freqüência e eficiência.

Cada parcela de $\operatorname{Cr} \$ 50,00$ ou mais até $\operatorname{Cr} \$ 99,90$ do salário constitui um ponto. Cada ano de serviço efetivo corresponderá a $2 \%$ do número indicativo do salário individual. Para a assiduidade haverá uma escala em que a freqüência integral corresponderá a $20 \%$ daquele número, sendo a parcela a ela relativa inversamente proporcional até ao máximo de 10 . A da eficiência será fixada livremente pelo empregador até ao máximo de $30 \%$ do mesmo número. 
Se até 90 dias da data do balanço não estiver organizado o plano de participação, a distribuição será feita considerando-se apenas o salário individual e a antiguidade na emprêsa.

Os participantes não empregados contarão sòmente salário e antiguidade. Será salário a remuneração pro labore escriturada em despesas gerais ou contas subsidiárias, dentro dos limites fixados pela lei do impôsto de renda.

6) Pagamento - Dentro de 90 dias da data do balanço a emprêsa afixará cópia em local apropriado, juntamente com a demonstração da conta de lucros e perdas e um resumo dos cálculos efetuados para os fins desta lei. Dentro do mesmo prazo a emprêsa entregará a cada empregado uma "nota de participação nos lucros" da qual constem, discriminadamente: a) o lucro partilhável e b) o cálculo da parte que caberá ao empregado de acôrdo com - plano de participação adotado. Na demonstração da conta de lucros e perdas a despesa de salários a que se referem os lucros deverá figurar destacadamente. O empregado terá o prazo de 30 dias para fazer, perante a emprêsa, qualquer impugnação à "nota de participação".

O pagamento da participação poderá ser feito de uma só vez ou em quatro prestações, no máximo, até 20 de dezembro de cada ano. Quando a participação fôr igual ou inferior a $1 / 24$ do salário anual seu pagamento será efetuado de uma só vez, por ocasião do Natal.

Tôda a vez que a participação individual exceder $1 / 12$ do salário percebido durante o ano o excesso será depositado em nome do empregado, na própria emprêsa, em conta especial, vencendo juros não inferiores a $6 \%$ ao ano, ou, se o empregador preferir, em conta especial em caixas econômicas ou em bancos de que a União ou os Estados sejam acionistas majoritários. Sòmente serão permitidas retiradas dessa conta: a) para integrar, no todo ou em parte, capital que o empregado tenha subscrito ou venha a subscrever na emprêsa; $b$ ) para aquisição de casa própria; c) para compensar, até ao máximo de $1 / 24$ do salário 
anual, a falta ou deficiência de participação nos lucros; d) quando cessar ou fôr rescindido o contrato de trabalho, em prestações mensais não superiores à metade do último salário mensal percebido.

7) Casos especiais - Nas sociedades de economia mista em que a maioria do capital pertencer à União, ao Estado ou ao Município a participação nos lucros será fixada livremente pelas respectivas administrações e obedecerá a planos por elas elaborados.

As emprêsas sem capital registrado ou com capital registrado de até $\mathrm{Cr} \$ 100 \mathrm{mil}$ e que tenham, em qualquer dos dois casos, até 20 empregados poderão optar pelo pagamento a cada um, como participação nos lucros, de 1/12 do salário individual percebido durante o exercício, dispensadas as exigências da lei. A lei não prejudicará os contratos de participação nos lucros, sejam quais forem as suas modalidades, existentes na data de sua vigência. Em tais casos a participação resultante da lei será levada à conta dos pagamentos devidos pela emprêsa aos empregados.

8) Natureza jurídica - Não se compreendem na remuneração do empregado, para os efeitos legais, inclusive da previdência social, as importâncias recebidas como participação nos lucros. Entretanto, constituirá crédito privilegiado em caso de falência ou concordata o total das importâncias devidas aos empregados, em razão da lei, inclusive os depósitos referidos quando examinamos o pagamento.

9) Critica - Como se viu, o projeto analisado institui a participação nos lucros sòmente pecuniária. Daí decorrem todos os seus defeitos, que o tornam perfeitamente inútil.

Para atender às objeções apresentadas à participação nos lucros - notadamente às de que a participação nos lucros provocaria a descapitalização e seria inflacionária - o projeto pràticamente reduz a nada a participação nos lucros. Com efeito, limita o seu valor global a $50 \%$ do 
total anual de salários e o seu valor individual a dois salários mensais, dos quais o empregado receberá anualmente apenas um.

Logo, em realidade, não institui a participação nos lucros, mas uma simples gratificação anual, o aguinaldo argentino. Aliás, hoje, tendo em vista a aprovação de outros projetos aqui não examinados (n. ${ }^{\circ} 3618 / 61$, do deputado Floriceno PAIXÃo e, anteriormente, n. ${ }^{\circ}$ s 158/47 e 563/ 48, do deputado PEDRoso JúnIoR), tal gratificação é objeto de outra lei, não de participação nos lucros .

Com efeito, a Lei n. ${ }^{\circ} 4$ 090, de 13 de julho de 1962, instituiu a gratificação de Natal para os trabalhadores, sendo regulamentada pelo Dec. n. ${ }^{\circ} 1881$, de 14 de dezembro de 1962. Estabelecem a "gratificação salarial" de um mês de salário por ano, vulgarmente denominada " $13 .^{\circ}$ salário" ou "13.0 mês". Em nenhum dêsses diplomas legais há qualquer referência à participação nos lucros. Em consequiência, não representam a lei ordinária que regulará o dispositivo do n. ${ }^{\circ}$ IV do art. 157 da Constituição Federal.

Deve, portanto, prosseguir a luta para a instituição, entre nós, da verdadeira participação nos lucros, a fim de dar cumprimento ao preceito constitucional.

- Outros projetos - Mesmo depois de aprovado o Projeto n. ${ }^{\circ} 1039 / 48$, vários outros foram apresentađos à Câmara dos Deputados: n. ${ }^{\circ} 1$ 929/56, QuEIROz FILHO; n ${ }^{\circ}$ 14/59, Paulo de Tarso; n. ${ }^{\circ} 1432 / 60$, Nelson CarNEIRO; n. ${ }^{\circ} 3$ 461/61, FERNANDO FERRARI; n. ${ }^{\circ} 3$ 759/61, JoAquim DURVal; n. ${ }^{\circ} 168 / 63$, Leopoldo Peres; n. ${ }^{\circ}$ $219 / 63$ e 531/63, JuAREz TÁvorA, e, n. ${ }^{\circ}$ 269/63, Jessé FrEIRE, êste sôbre acionariado operário.

Dêles, brevitatis causa, examinaremos apenas os mais originais, dos deputados QUeIRoz Filho, PAULO DE TARSo e JUAREZ TÁvORA, mesmo porque alguns, como o do deputado FERNANDo FERRARI, versam sòmente sôbre aspectos parciais do problema. 
1) Projeto $1929 / 56$, QueIroz Filho - Os aspectos originais dêsse projeto são: a) a criação de um conselho de representantes dos empregados, de 5 a 25 membros, para estudo e fiscalização dos planos de participação nos lucros; $b$ ) o valor global mínimo de $30 \%$ dos lucros; $c$ ) fixar para os participantes não empregados, como máximo, o limite de 5 vêzes a cota média dos empregados. Obviamente, incide êle nas mesmas críticas feitas ao Projeto n. $^{\circ} 1039 / 48$.

2) Projeto 14/59, Paulo de Tarso - Dispõe sôbre a política de incentivos à adoção, pelas emprêsas, do regime de distribuição de lucros aos trabalhadores. Tais incentivos são: a) dedução do valor global da participação nos lucros do lucro real tributável pelo impôsto de renda; b) prioridade, em igualdade de condições, para as operações com o Banco do Brasil, com o Banco Nacional do Desenvolvimento Econômico, com a Caixa Econômica Federal e congêneres, para as concorrências públicas e aprovação de contratos de qualquer espécie com entidades públicas, autárquicas e sociedades de economia mista federais; c) o lucro será o constante do balanço contábil da emprêsa.

Tal projeto é òbviamente inconstitucional, pois admite a participação nos lucros facultativa e indireta, enquanto o art. 157, n. ${ }^{\circ}$ IV, da Constituição de 1946 a estabelece obrigatória e direta.

3) Projeto 531/63, JuARez Távora - Êsse projeto reestrutura completamente a emprêsa, dela fazendo uma comunidade de capital, trabalho e direção. Considera os lucros bem comum a êles e que entre êles deve ser dividido. Para isso entende, entretanto, que deve haver correlação de direitos e deveres, que o projeto menciona minuciosamente. Admite para os dois elementos - o capital, de um lado, e o trabalho (tanto de execução, como de direção) - duas espécies de remuneração: a primária, representada pelos juros do capital e pelos salários de todos os que trabalham na emprêsa (suprimidas as retiradas e gratificações de diretores ), com o máximo dos 5 me- 
nores salários pagos pela emprêsa; e a secundária, consistente na participação nos lucros .

O projeto considera lucro líquido, lucro real ou lucro fiscal de um exercício social a diferença obtida entre o lucro bruto, acrescido das receitas diversas (juros e rendas diversas), e as seguintes deduções: a) juros máximos de $10 \%$ ao ano sôbre o capital social anualmente reajustado segundo a aplicação dos coeficientes estabelecidos oficialmente para compensar as desvalorizações da moeda; $b$ ) as deduções legais previstas no regulamento para cobrança e fiscalização do impôsto de renda, nomeadamente as seguintes, ligadas à constituição de fundos de garantia do capital e do trabalho e de provisóes contra riscos da emprêsa: I) fundo de depreciação e renovação de acervo; II) fundo de amortização de capital social, quando legal ou contratualmente previsto; III) cotas para amortizações de empréstimos e financiamentos não incorporáveis ao capital social da emprêsa; IV) cotas de assistência social, inclusive a destinada ao pagamento de abono-família; V) cotas de previdência social; VI) provisões contra riscos da emprêsa.

A participação no lucro das sociedades anônimas será feita com base no lucro fiscal ou real, ou já nos resultados apresentados no balanço geral e na demonstração de lucros e perdas, correspondentes ao exercício e aprovados pela assembléia geral de acionistas.

A participação global do trabalho (nêle incluídos os elementos da direção) nos lucros da emprêsa será proporcional à contribuição de ambos para a produção da emprêsa, durante o ano social, e se determina, percentualmente, pela relação entre as despesas gerais com o pessoal e as despesas diretas do custeio da produção, durante o ano correspondente.

Incluem-se no cômputo das despesas gerais com o trabalho as seguintes parcelas: a) as remunerações primárias pagas durante o ano ao trabalho, aí incluídos os elementos da direção; $b$ ) as cotas de assistência, inclusive abono-família, e de previdência social a cargo da emprêsa; 
c) as comisões e percentagens, tarefas ou empreitadas, e gratificações pagas pela emprêsa.

Excluem-se de tal cômputo: a) as diárias e ajudas de custo para viagens; $b$ ) vestuários e acessórios distribuídos ao pessoal para prestação de serviços nos locais de trabalho.

As despesas de custeio direto da produção incluem as seguintes parcelas: a) os juros pagos como remuneração primária ao capital social; $b$ ) os salários pagos como remuneração primária ao trabalho, nêle incluídos os elementos integrantes da direção; c) descontos e juros de empréstimos e financiamentos; $d$ ) impostos gerais, excluído o de renda; e) cotas de assistência e de previdência sociais a cargo de emprêsa; $f$ ) cota destinada ao fundo de depreciação e renovação do acervo; $g$ ) despesas diversas ligadas ao processo de produção.

Nos casos de emprêsas cujas atividades sejam as de empreitadas de construção de estradas e semelhantes (artigo 56 do Decreto n. ${ }^{\circ} 47373$, de 7 de dezembro de 1959) os salários anuais e as receitas serão os relativos ao lucro apurado parcial ou totalmente na respectiva empreitada, rubricados como operações pendentes.

A determinação da cota individual de cada elemento do trabalho no lucro da emprêsa será feita em função do tempo de serviço e do total de salários nela recebidos durante o ano.

O tempo de serviço é computado sob a forma de "pêso de antiguidade", variável de 1 a 3 , da forma abaixo:
a) de 2 a 4 anos - pêso 1,00;
b) de 5 a 7 anos - pêso 1,50;
c) de 8 a 10 anos - pêso 2,00;
d) além de 10 anos - pêso 3,00 .

A participação correspondente ao salário será determinada sob a forma de "pontos-salários", multiplicando-se um milésimo do salário anual pelo "pêso de antiguidade". Em 
função dêsses dois coeficientes será obtido o "índice de tateio" dividindo-se o valor da participação global do trabalho pelo total de "pontos-salários" de todos os elementos do trabalho. Finalmente, a determinação da cota individual de participação de cada elemento do trabalho é feita multiplicando-se o número de "pontos-salários" do trabalhador pelo "indice de rateio".

A participação do capital nos lucros líquidos verificados será o saldo disponível após a dedução da cota global de participação de trabalho, aí incluídos or elementos da direção.

De acôrdo com a decisão aprovada pela assembléia-geral dos acionistas, a distribuição do lucro líquido apurado em cada exercício será feita, com igual critério para o capital, o trabalho de direção, pelas seguintes formas combinadas: a) em espécie, como bonificação posta à disposição de cada elemento do trabalho, da direção e do capital; $b$ ) em novas ações ordinárias, preferenciais e do trabalho, emitidas em correspondência com a cota deduzida para o fundo de ampliação da emprêsa, ou para a constituição de qualquer reserva que se possa incorporar ao capital social. A bonificação em espécie, atribuída ao trabalho, corresponderá, no mínimo, a um mês de salário, em substituição do atual 13..$^{\circ}$ salário, criado pela Lei $n .^{\circ} 4090$, de 13 de julho de 1962. As ações do trabalho gozarão dos mesmos direitos das ações orçinárias, exceto as limitações à circulação e ao direito de voto. A respeito, o mesmo deputado apresentou o Projeto n. ${ }^{\circ} 219 / 63$.

Capital e trabalho serão representados, paritàriamente, no conselho fiscal da emprêsa. O conselho fiscal acompanhará a apuração das cotas destinadas à constituição dos fundos de garantia do capital e do trabalho, e de provisões contra riscos da emprêsa, bem como a administração dêsses fundos.

As eleições das diretorias das sociedades anônimas se farão pelo critério proporcional, determinando-se o cociente eleitoral mediante a divisão do número total das ações cr- 
dinárias e ações do trabalho, pelo número de diretores que compuserem a diretoria.

O trabalho elegerá tantos diretores quantas vêzes o número de ações do trabalho comportar o coeficiente eleitoral, computando-se como inteiro a fração superior a um meio. Quando um diretor não puder, por qualquer motivo, completar o seu mandato, a eleição para substituí-lo far-se-á exclusivamente pelo grupo de acionistas do capital ou do trabalho que o haja eleito anteriormente. Independentemente de o trabalho dispor de número de ações suficiente para eleger um diretor, poderá a direção, de acôrdo com os detentores dó capital, organizar uma direção de serviços sociais, entregando-a a representante do trabalho. Em qualquer tempo poderão o trabalho e a direção organizar, de comum acôrdo, um conselho de emprêsa destinado a examinar permanentemente as questões de interêsse comum do capital e do trabalho na emprêsa, e, eventualmente, a procurar solução pronta e construtiva para divergências nela surgidas e que possam conduzir a impasses prejudiciais à harmonia dos fatôres de produção $\mathrm{e}$ à sua produtividade.

As sociedades comerciais não estruturadas sob a forma de sociedade por ações destinarão, para remuneração secundária do trabalho, até 90 dias após o balanço geral, em moeda nacional, $30 \%$, no mínimo, do lucro fiscal, ou lucro presumido, calculado de acôrdo com o Regulamento para Cobrança e Fiscalização do Impôsto de Renda. Na determinação da participação do trabalho no lucro apurado será levada em conta, como nas sociedades por ações, a remuneração primária devida ao capital social. O cálculo da participação individual dos elementos do trabalho (aí incluídos os de direção) nos lucros líquidos far-se-á pelo mesmo processo especificado. É facultado às sociedades de que trata o presente artigo distribuir, em ações de trabalho, parte dos lucros cabíveis ao trabalho, devendo nesse caso os portadores de tais ações transformarem-se em sócios comanditários. 
As divergências que surgirem com a aplicação dos planos de participação do trabalho nos lucros da emprêsa, bem como com a aplicação da lei em foco, serão julgadas pelos delegados regionais do Impôsto de Renda do Estado em que estiver localizada a sede da emprêsa, com recurso voluntário para a Primeira Câmara do Primeiro Conselho de Contribuintes, observados os prazos e a forma processual estabelecidos no Regulamento do Impôsto de Renda.

Êsse projeto é o melhor de todos até hoje apresentado, sob todos os aspectos. A reestruturação da emprêsa nêle proposta atende exatamente aos anseios dos que desejam a reforma da emprêsa. Adota, como se viu, o sistema misto, mantendo pequena parte pecuniária (o atual $13 .^{\circ}$ salário) e convertendo o restante da participação nos lucros individual em ações de trabalho. Estas diferem das ordinárias apenas por sofrerem restrições quanto à orientação e ao direito de voto, restrições, aliás, não esclarecidas no projeto. Estabelece a participação dos empregados na direção da emprêsa e no conselho fiscal, de forma proporcional. Aconselha ainda a criação de um conselho de emprêsa .

Seu único defeito, a nosso ver, reside na sua própria excelência. Cremos ser muito difícil no momento a sua aprovação, embora sejamos inteiramente a seu favor. Com efeito, se a simples idéia da participação nos lucros tem encontrado até hoje resistência tão grande que 18 anos após sua inscrição na Constituição ainda não se conseguiu regulá-la em lei, quanto maior não será a resistência a tão radical reforma da emprêsa? Pensamos, por isso, que uma solução também acionária mais modesta talvez tivesse maior probabilidade de vingar.

- Projetos do Senado - No Senado Federal foram apresentados os Projetos n. ${ }^{\circ} \mathrm{S} 28 / 51$, de JoÃo VillasBOAS; 12/63, de Nelson Maculan, e 96/63, de Eurico ReZENDE, além do já citado Projeto n. ${ }^{\circ} 333 / 52$, que vem da Câmara dos Deputados (1039/48), e mais o de . $^{\circ}$ $47 / 64$, de GouvÊA VIEIRA. 
Em 22 de abril de 1964 o Senado Federal aprovou o requerimento n. ${ }^{\circ} 78$, de 1964 , do Senador JEFFERSON AGUIAR, que propunha a tramitação em conjunto daqueles projetos, com exclusão do de $n .^{\circ} 12 / 63$. E a 24 do mesmo mês aprovou a constituição de uma comissão especial de 7 membros para, no prazo de três meses, proceder ao estudo das proposições relacionadas com a participação nos lucros. Ésse prazo foi posteriormente prorrogado por mais três meses.

1) Projeto n.o $28 / 51$ - Êsse projeto apresenta como inovação: a) valor global de $30 \%$; b) para determinar o valor individual leva em conta a produção do empregado, anotada em cadernetas individuais; c) adota a forma diferida: $75 \%$ entregues a êle e $25 \%$ depositados no instituto de aposentadoria e pensões respectivo para sòmente serem retirados nas hipóteses previstas no presente artigo em Análise do Projeto $1039 / 48$ (333/52), item 6, fim do último parágrafo; $d$ ) proíbe, expressamente, que as emprêsas compensem período de lucro com período de prejuízo; e) para os casos em que não é obrigatória a escrita regular a participação nos lucros será calculada, na forma da lei do impôsto de renda, sôbre o montante das respectivas operações, distribuindo-se apenas à base do salário; $f$ ) obriga as emprêsas que já não o hajam feito, ao pagamento da participação nos lucros, à base de $10 \%$, desde a data da Constituição Federal até à vigência da lei; g) permite o exame da escrita patronal.

Sôbre as principais inovações, observaremos apenas que a consideração da produção no valor individual confunde a participação nos lucros com o salário-incentivo. $\mathbf{E}$ o efeito retroativo da letra $f$ supra fere o disposto no art. 141, $\S 3 .^{\circ}$, da própria Constituição Federal. Com efeito, por fôrça do que dispõe o n. ${ }^{\circ}$ IV do seu art. 157, a participação nos lucros sòmente será devida depois de regulada em lei.

2) Projeto n. $12 / 63$ - Apresenta apenas duas novidades, ambas concernentes ao valor individual. Manda calculá-1o $70 \%$ considerando-se o tempo de serviço e os en- 
cargos de família, e $30 \%$ segundo a remuneração e a contribuição feita ao impôsto de renda. Divide-o: $50 \%$, pagos em dinheiro; $25 \%$, depositados, com juros de $8 \%$, nos mesmos têrmos do anterior; e $25 \%$ pagos em títulos ou ações, inclusive da própria emprêsa.

Observaremos que são desarrazoadas as referências aos encargos de família e às contribuições do empregado para o impôsto de renda.

3) Projeto n. ${ }^{\circ}$ 96/63 - Inova ao dispor sôbre a democratização do capital das emprêsas e a participação do trabalhador rural na exploração das propriedades agropecuárias. A primeira se fará pelo pagamento de $90 \%$ do valor individual em ações nominativas, preferenciais, sem voto ("ações de participação"), das emprêsas, e pela redução do impôsto de renda às que admitirem como acionistas seus empregados e, na falta dêstes, a estranhos. A segunda, pela cessão aos trabalhadores rurais e seus dependentes, para que as explorem, de $10 \%$ das terras, preparadas e semeadas pelos proprietários, e de inseticidas e fertilizantes, os dois últimos a serem pagos na colheita. No caso de pecuária a área será de 2 hectares de terras preparadas e semeadas por família ou grupo de 3 solteiros. Os proprietários poderão, entretanto, optar pela distribuição ao empregado de $5 \%$ do valor da venda de seus produtos ou de animais nascidos no decorrer do ano.

Os empregados acionistas poderão eleger um membro do conselho fiscal e um diretor com funções consultivas e acesso a todos os informes sôbre as atividades da emprêsa. O mérito - representado, para nós, pela introdução da participação nos lucros acionária - desaparece diante dêstes dois graves defeitos: a) as ações são preferenciais, sem direito de voto e livremente transferiveis após a terminação do contrato de trabalho; $b$ ) seu valor, para cada empregado, é restrito a $1 \%$ do capital da emprêsa.

- Projetos e anteprojetos de Código do Trabalho - Foram até hoje apresentados dois projetos de Código do Trabalho: n. ${ }^{\circ} 606 / 50$, do deputado Segadas VianNa, e n. ${ }^{\circ}$ 
429/55, do deputado CARLOS LACERDA, êste último elaborado pelo Dr. Dorval Lacerda. Houve, a seguir, dois anteprojetos: o do Professor Evaristo DE MORAES FILHO e êsse mesmo revisto por uma comissão integrada por êle próprio e pelos professôres MOzART VICTOR RUSsomano e José Martins Catharino.

1) Projeto Segadas Vianna - Cogita da participação nos lucros no Capítulo III do Título III (Contrato Individual de Trabalho), do art. 285 ao art. 306. Reproduz, pràticamente, o Projeto n. ${ }^{\circ} 1039 / 48$, a que já nos referimos.

2) Projeto CARLos LACERda - Cuida da participação nos lucros no Capítulo VI do Título II (Das Normas Gerais de Proteção ao Trabalho), nos arts. 161 a 178 . São do seu próprio autor estas palavras: "Êste capítulo resulta do estudo proposto pela notável monografia intitulada "Um Ensaio de Justiça Distributiva", de autoria do General JuAREz TÁvora. Essa monografia fêz afirmações doutrinárias, mas não chegou a esboçar solução prática. Para isso tratamos de aproveitar e reajustar às normas do Código os projetos de lei do Deputado Paulo Sarasate (1948, Projeto n. 1 039) e do Deputado DanIEL FARAco (1947, Projeto n. 5 )".

3) Anteprojeto Evaristo de Moraes Filho — Ocupa-se da participação nos lucros no Capítulo IV do Título VI (Da Organização da Emprêsa), arts. 631 a 662, e no Capítulo V do mesmo Título, arts. 663 a 666 (Do Acionariado de Trabalho). Assim se manifesta o autor em sua justificação: "Quanto à participação nos lucros, aproveitamo-nos em grande parte, do projeto aprovado pela Câmara dos Deputados e que, há muito, se encontra no Senado Federal. Obedece aos ditames constitucionais, com a participação direta, obrigatória e geral, mas permite a associação do empregado à emprêsa e a constituição de uma conta de reserva para os momentos difíceis da vida do empregado ou para com ela integrar o seu capital na 
emprêsa", e ainda: "O acionariado do trabalho é facultativo, tendo o anteprojeto o cuidado de uni-lo ao regime da participação. A conta especial em nome do empregado, sempre que a participação fôr superior a um duodécimo, poderá ser por êle utilizada para integrar capital subscrito na própria emprêsa. Desde o comêço, os acionariados vêm cercados de certa aura de romantismo e utopia. Não nos iludimos. Não reeditamos as famosas ações do trabalho francesas adotadas por lei especial há meio século. As ações são da mesma natureza que as demais, comuns. Daí o aumento automático e necessário do capital social". A inovação consistiu em fazer intervir na fiscalização da participação nos lucros os conselhos de emprêsa criados pelo anteprojeto.

4) Anteprojeto revisto - Manteve a participação nos lucros no Capítulo IV do Título V (Da Organização da Emprêsa), arts. 466 a 495, e o acionariado do trabalho no capítulo seguinte, arts. 496 a 498 . Várias foram as modificações introduzidas: a) supressão do art. 638, sôbre participação nos lucros aos não empregados que trabalhassem na emprêsa com a conseqüente supressão do art. 649; b) aumento de $10 \%$ para $12 \%$ da remuneração do capital (art. 640); c) supressão da referência ao delegado sindical, no art. 643; d) substituição da expressão "Tribunal Regicnal do Trabalho", no parágrafo único do artigo acima, por "Justiça do Trabalho"; e) inverteu o critério do parágrafo único do art. 644, para o cálculo do valor individual, tornando obrigatórias a freqüência e a eficiência, e facultativa a antiguidade - o que é mais razoável e, conseqüentemente, eliminou a referência à antiguidade no art. 648 ( 482 revisto); f) no art. 650 (483 revisto) corrigiu a expressão "perdas e danos" para "lucros e perdas"; g) no art. 653 (486 revisto) suprimiu a expressão: ". . . usando da faculdade constante do art. 19 do Código Comercial"; $h$ ) suprimiu no art. 662 (495 revisto) a palavra "convenções"; i) suprimiu o art. 665, que dispunha, quanto ao acionariado do trabalho: "O capital social deve ser aumentado na medida correspondente". 
CONCLUTẼ̃o

\section{A. A Verdadeira Participação nos Lucros}

De todo o exposto resulta claramente - assim o esperamos - a conclusão de que a verdadeira participação nos lucros é a obrigatória, direta e acionária.

Admitida a fórmula do Projeto n. $1039 / 48$, estabelecidos como limites mínimo o de $20 \%$ e máximo o de $40 \%$ dos lucros tributados pelo impôsto de renda, distribuído êsse valor global, obrigatòriamente, de acôrdo com os critérios de importe da remuneração anual, antiguidade, assiduidade e eficiência, para cada empregado, a respectiva cota seria integralmente convertida em ações ordinárias ou cotas-partes do capital das emprêsas, que seria aumentado ad hoc. Tôdas elas teriam, obrigatòriamente, a forma de sociedades por cotas ou por ações.

Destarte, os empregados tornar-se-iam, automàticamente, sócios do empregador. Cada um dêles - visto como omnis homo potest plures personas sustinere -, embora continuando a ser empregado regido pela legislação social passaria a ser um acionista ou cotista, regulado pelas leis de sociedades por ações ou de sociedades por cotas de responsabilidade limitada. Pràticamente, não haveria alteração nessas leis, a não ser o fato de que as ações sempre nominativas - ou cotas sòmente seriam transferíveis por terminação do contrato do trabalho, e isso mesmo exclusivamente a outros empregados ou aos proprietários da emprêsa, observada essa ordem.

Assim, sem grandes transformações, seriam atingidos, ao mesmo tempo, os três escopos da reforma da emprêsa, segundo a Doutrina Social Católica: participação nos lucros, cogestão e copropriedade.

\section{B. Sua Influência na Solução da Questão Social}

Muito ao contrário do que se afirma ocorreria com a simples participação nos lucros pecuniária, a participação nos lucros acionária, se não a resolvesse, muito influiria para a solução da Questão Social. 
A demonstração dessa asserção não vamos fazê-la com palavras, mas com fatos.

Já mostramos o êxito extraordinário da participação nos lucros no México, mesmo sem ser acionária. O saudoso deputado Professor QUEIROz Fil.ho assim se exprimiu no item 3 da justificação do seu Projeto n.o 1 929/56: "Vejamos, porém, em dados concretos, os frutos anunciados pelo conselho norte-americano das indústrias que trabalham em regime de participação de lucros: 1) sessenta por cento a mais na remuneração global dos trabalhadores, em confronto com os melhores salários pagos em outras indústrias do mesmo ramo; 2) quarenta por cento de aumento da eficiência em produção por empregado; 3 ) sessenta e seis a oitenta por cento de maior lucro para a emprêsa considerada em conjunto, isto é, trabalhadores e acionistas; 4) trinta a quarenta por cento de redução nos preços para o consumidor de artigos manufaturados; 5) renovação do quadro de empregados muito reduzida e, em certos casos, totalmente eliminada; 6) grande aumento nas sugestões dos trabalhadores quanto a inovações consideradas favoráveis à vida da emprêsa; 7) redução das queixas e das greves que se tornaram cada vez mais escassas; 8) virtual desaparecimento da vigilância, que se tornou desnecessária; 9) número crescente de trabalhadores qualificados, que desejam ingressar nas emprêsas sob regime de participação; 10) finalmente, aponta-se, como resultado do sistema, o clima de compreensão, de cooperação e de ordem que preside a vida da emprêsa, onde, afinal, os agitadores não têm função a exercer". E isso nos Estados Unidos, com participação facultativa e pecuniária. Poderíamos acrescentar ainda os seguintes fatos: "A Fundação de Pesquisas sôbre Participação ios Lucros de Chicago, num estudo recente de catoize emprêsas varejistas, das quais sete tinham planos de participação, constatou que as companhias que repartiam os lucros com os empregados prosperavam mais que as outras. $O$ estudo de alguns dos maiores varejistas do país - inclusive Gimbel Brothers, Marshall Field \& Co., Sears, Roebuck \& Co., J. C. Penney Co. e R. H. Macy \& Co. - revelou 
que as suas vendas, valor líquido, lucro bruto e valor das ações eram superiores aos das emprêsas sem aquêles planos"; "Em 1958 sete firmas varejistas tinham lucros líquidos equivalentes a 11,3 por cento; os das emprêsas sem tais planos, 6,93 por cento. No mesmo ano os lucros por empregado das companhias com planos de participação atingiram US\$ 687 contra US\$ 461 das companhias sem êles. Demais, os varejistas com planos de participação conseguiram manter sua margem de superioridade nesses dois setores nos sete anos de 1952 a 1958 . O estudo demonstrou também que o dólar dos acionistas cresceu mais ràpidamente nas companhias com plano de participação; cada dólar investido teve um valor de $\$ 1,37$ entre 1952 e 1958 , contra $\$ 0,95$ nas outras. Como era de esperar, os dividendos e o valor das ações das emprêsas com planos de participação foram também superiores"; "exemplo típico do plano de pagamento em dinheiro é o da Sanborn Company, que começou seu plano de participação em 1917 e hoje destina 25 por cento do lucro a êsse fim. Em 1959 os empregados da firma receberam a média de US\$ 582 do "bôlo" total de US\$552 879. O Sr. Jenks declara que mais de 90 por cento dos acionistas concordam que o progresso da companhia se deve principalmente ao plano em aprêço. Demais, eliminou dificuldades trabalhistas; atraiu trabalhadores do mais alto tipo e estimulou a vontade de trabalhar com afinco". ${ }^{27}$

Convém repetir que tôdas as objeções são contra aquela forma de participação nos lucros! Entretanto, atestam o seu êxito, além dos fatos já apontados, mais êste, recentíssimo: "Operários e GM fazem acôrdo - O Sindicato de Trabalhadores em Indústrias Automobilisticas e a $\mathrm{Ge}$ neral Motors concluíram acôrdo que concede aos empregados uma participação nos lucros da sociedade. $\mathbf{O}$ acôrdo foi assinado uma hora depois da marcada para declaração de uma greve". ${ }^{28}$ Outros exemplos são citados em bri-

27) "Participação dos Empregados nos Lucros dia Indústria nos EUA", $O$ Estado de São Paulo (suplemento comercial e industrial), de 29-12-1960.

28) Cf. nota 25. 
lhante entrevista do esclarecido comerciante Sr. OswaLdo TAVARES. ${ }^{20}$

Por outro lado, fala-se muito atualmente em democratização da emprêsa, pela conversão das sociedades anônimas em sociedades abertas. A própria legislação viria estimulá-la, como se vê no Dec. n.o 54 105, de 6 de agôsto de 1964, que criou o Fundo de Democratização do $\mathrm{Ca}$ pital das Emprêsas (FUNDECE). Diz no art. 4. ${ }^{\circ}$, parágrafo único, letra a: "As operações do Fundo consistirão em empréstimos com prazo entre 6 e 36 meses, com períodos de carência adequados e mediante garantias reais oferecidas pela própria emprêsa ou por seus acionistas. Parágrafo único. Garantidas as condições usuais de segurança do reembôlso, o Fundo dará prioridade às solicitações de emprêsas que: a) aceitem fórmulas que envolvam a abertura de seu capital social".

Além disso, o Projeto n. ${ }^{\circ} 47$, de 1964, do Senador GouvÊA VIEIRA, pretende assegurar aos empregados o direito de preferência para subscrever $20 \%$ dos aumentos de capital realizados por sociedades anônimas. Nesse sentido escreveu KURT E. WEIL: "Seria ainda necessário que houvesse modificações e adaptações em leis atuais ou em andamento no Congresso Nacional para que as emprêsas tivessem possibilidade de considerar reinvestimentos de lucros como aumentos de capital que, transformados em ações, pudessem ser distribuídos nessa qualidade para a participação nos lucros — já que é intenção do Govêrno diminuir o pagamento de dividendos pela aplicação do lucro da emprêsa no aumento do próprio capital ou em ações de indústrias de base (Projeto n. $.^{\circ} 325 / 61$ do Executivo, que altera a Lei n. 2862 , de 4/9/56, e disciplina a aplicação de capitais por meio de impôsto de renda) dando benefícios na taxação." 30

29) Cf. nota 26.

30) KURT E. WeIL, "A Participação do Empregado no Lucro da Emprêsa", Revista de Administração de Emprêsas, vol. 2, n. ${ }^{\circ}$ 4, pág. 28. 
E em várias sociedades de economia mista já existe a participação nos lucros, como é o caso da Fábrica Nacional de Motores (Estatutos, art. 25, letra c), da Companhia Siderúrgica Nacional (art. 49), da Companhia Nacional de Álcalis (art. 28). O deputado Fernando FerRari, no Projeto n. ${ }^{\circ} 3461$, de 1961, pretendeu instituir a participação dos empregados e servidores nos lucros de tôdas as sociedades de economia mista e emprêsas públicas.

Aliás, várias emprêsas já têm adotado o sistema de facilitar aos seus empregados a aquisição de suas ações, com ótimos resultados. Podemos citar, de momento, sem ter efetuado nenhuma pesquisa a respeito, as seguintes: Cia. Brasileira de Tratores, ${ }^{31}$ Listas Telefônicas Brasileiras, ${ }^{32}$ Laboratório Maurício Villela. ${ }^{33}$

Aprovemos, pois, definitivamente, a participação nos lucros acionária, se desejamos, na verdade, resolver a Questão Social, com a sobrevivência dos princípios da propriedade privada e da livre iniciativa, evitando, assim, a sua coletivização com estatização. Tornemos capitalistas os proletários para evitar que os capitalistas sejam feitos proletários.

31) "Operários capitalistas", Fôlha de São Paulo de 19-3-1963.

32) "Democratização do Capital", Observador Trabalhista, 1964, pág. 56.

33) "Labcratórios Maurício Villela democratizam seus capitais: 150 funcionários acionistas", Fôlha de São Paulo (caderno de Economia e Finanças), de 4-10-1964. 